\title{
Drastic changes of the amphipod fauna in northern Germany and the displacement of Gammarus lacustris G.O. Sars, 1864 to relict habitats/status
}

\author{
Ulrich Meßner and Michael Lothar Zettler* \\ Leibniz Institute for Baltic Sea Research Warnemünde, Seestraße 15, 18119 Rostock-Warnemünde, Germany
}

Received: 7 December 2020 / Accepted: 31 March 2021

\begin{abstract}
The amphipod fauna of Central Europe has changed dramatically over the last century. This change has increased dramatically over the past 30 years. This dynamic is well documented in northeast Germany. This study places it in a landscape-ecological context. An example of a displacement is Gammarus lacustris G.O. Sars, 1864, a circumpolar species with a variety of habitats, but relegated to relic habitats. The species turns out to be a very weak competitor. Already with the immigration of Gammarus roeselii Gervais, 1835 (probably in the 1960s), it became a relic species in northeast Germany. Massive waves of introduction of Pontocaspian species of the genera Dikerogammarus, Pontogammarus and Echinogammarus a few decades later intensified this process for this and other species.
\end{abstract}

Keywords: Species replacement / competition / neozoan species / animal geography / land use

\begin{abstract}
Résumé - Changements profonds de la faune d'amphipodes en Allemagne du Nord et déplacement de Gammarus lacustris G.O. Sars, 1864 vers des habitats/statuts reliques. La faune d'amphipodes d'Europe centrale a changé de façon importante au cours du siècle dernier. Ce changement a augmenté de façon considérable au cours des 30 dernières années. Cette dynamique est bien documentée dans le nord-est de l'Allemagne. Cette étude la replace dans un contexte d'écologie du paysage. Un exemple de déplacement est celui de Gammarus lacustris G.O. Sars, 1864, une espèce circumpolaire aux habitats variés, mais reléguée dans des habitats relictuels. L'espèce s'avère être un compétiteur très faible. Déjà avec l'immigration de Gammarus roeselii Gervais, 1835 (probablement dans les années 1960), elle est devenue une espèce relique dans le nord-est de l'Allemagne. Des vagues massives d'introduction d'espèces pontocaspiennes des genres Dikerogammarus, Pontogammarus et Echinogammarus quelques décennies plus tard ont intensifié ce processus pour cette espèce et d'autres.
\end{abstract}

Mots clés : Remplacement d'espèces / compétition / espèces néozoaires / géographie animale / utilisation des terres

\section{Introduction}

Gammarus lacustris G.O. Sars, 1864 is one of the most circumpolar amphipod species of the northern hemisphere (Altermatt et al., 2019). Together with Gammarus pulex Linnaeus, 1758 the species was the first colonizer of the late Pleistocene landscape when the ice cover retreated about 12,000 years ago (Segerstråle, 1954). Both species have very likely been the dominant amphipod species in the inland water bodies of Northern Germany for 12,000 years. The occurrence of G. lacustris for all of Germany is in the late Pleistocene landscape of northern Germany and on the edge of the Alps.

\footnotetext{
${ }^{*}$ Corresponding author: michael.zettler@io-warnemuende.de
}

Glacial relics such as Pallaseopsis quadrispinosa (G.O. Sars, 1867) and Monoporeia affinis (Lindström, $1855)$ were restricted to the deep zones of large lakes as a result of global warming. This situation changed with the increasing connection of originally isolated catchment areas through the expansion of canals and associated increasing transport of goods (Tittizer et al., 2000; Tittizer, 2001). Gammarus roeselii Gervais, 1835 originates from Southeastern Europe and Asia Minor. It is probably one of the early invasive species (Karaman and Pinkster, 1977; Jażdżewski and Roux, 1988; Grabowski et al., 2017; Csapó et al., 2020). The exact time of arrival of Gammarus roeselii in the study area is not documented. However, we assume that the species may have arrived here only after the 2 nd World War, as there are reliable accounts of its presence as 


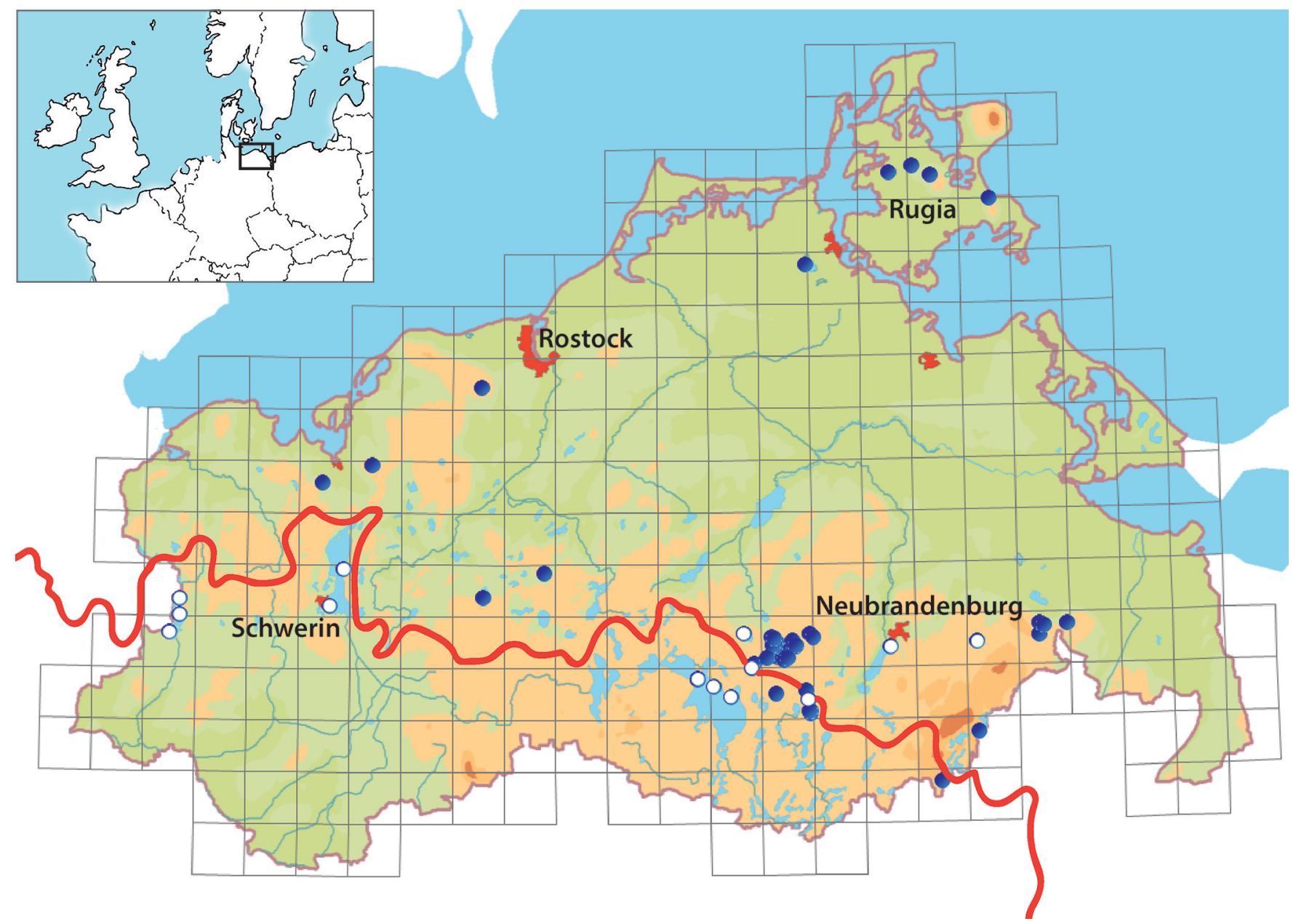

Fig. 1. The study area in North-East Germany, State of Mecklenburg-Western-Pomerania. Red line: Main watershed between North Sea and Baltic Sea. Circles: Records for Gammarus lacustris G.O. Sars, 1864. Empty circles: extinct.

early as 1960 (personal communication, Joachim Rahn). Chelicorophium curvispinum (G.O. Sars, 1895) and Echinogammarus ischnus (Stebbing, 1899) are two further early immigrated species. Their arrival in the study area is traceable by data. The significant increase of newly immigrated species around the turn of the millennium is well documented for the study area.

This current dynamic is accompanied by the decline of G. lacustris. The species conservation status was already considered as critically endangered at the end of the 20th century (Zettler, 1999b). Current data show that G. lacustris only occurs in very isolated waters and continues to decline. Considering the immigration of many invasive species from the Ponto-Caspian region, G. lacustris is becoming a new ice age relic. Our research classifies and interprets the current distribution patterns of the amphipod species in the context of landscape ecology.

\section{Materials and methods}

A Crustacea database with currently 6,700 records exists for northeastern Germany (state of Mecklenburg-Western Pomerania). 3,200 of these records are amphipods. This database is based on data collected over the past three decades and contains information from literature, museum collections (since 1901) and, since the 1980s, most of the data from our own research in Mecklenburg-Western Pomerania. Additional records were made in Schleswig-Holstein and Brandenburg (including Berlin), but no data with a comparable spatial resolution is known for these other German federal states.

On the basis of these data, the immigration histories of individual species are traced and spatial and temporal changes are shown.

\section{The study area}

The Weichsel Glacial Stage shaped the character of the northeast Germany landscape. It is a geologically very young landscape. It lies between Berlin and the Baltic Sea coast. Mecklenburg-Western Pomerania has more than 2,200 lakes (larger than $1 \mathrm{ha}$ ), plus countless small and very small water bodies. The same applies to the east of Schleswig-Holstein and the north of Brandenburg. The main terminal moraine of the Pomeranian stage is the watershed between the North Sea and the Baltic Sea (Fig. 1).

The water body types are divided into depressions with no outflow, lakes of various sizes and hydrology, and the former glacial meltwater rivers and streams (Fig. 2). Except for acid 


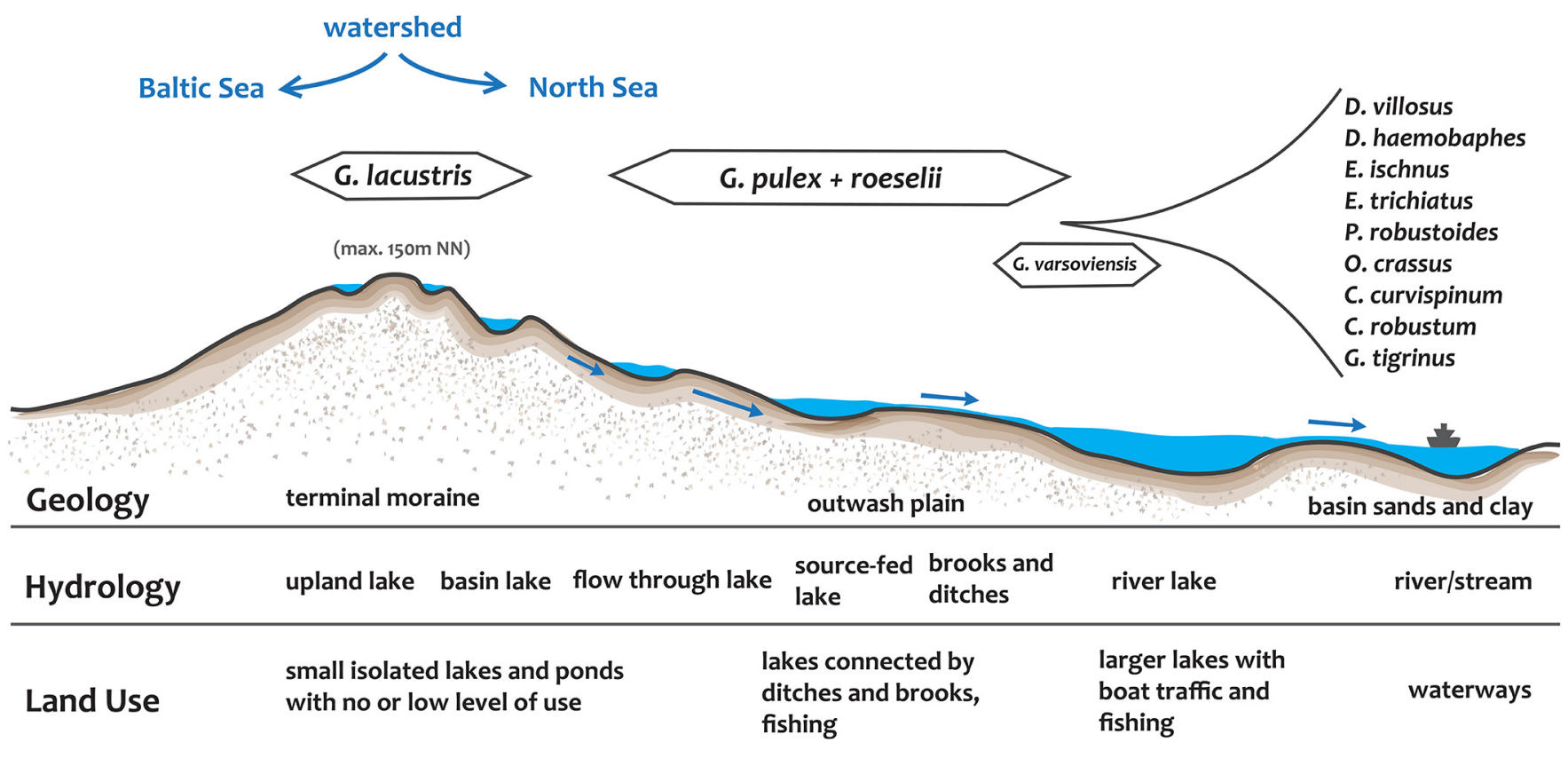

Fig. 2. Landscape structure and occurrence of amphipod species by water body type, exemplary for an area southwest of the main watershed in the direction of the river Elbe/North Sea.

moorland water bodies, all of these young glacial water bodies are well supplied with lime.

The intensification of land use in the 19th century brought about major changes in the water bodies. Already in the 13th century the construction of water mills began (Kaiser et al., 2012). With it, hydrological conditions changed increasingly (merging of catchment areas, changes in water levels). During the industrial revolution in the 18th and 19th century, canals were built for rafting and shipping. At the same time, the drainage of the moors was encouraged, which resulted in the first eutrophication of water bodies (Schönfelder and Steinberg, 2004). The drainage and eutrophication of the landscape reached its peak in the modern land management of the modern age (Mathes et al., 2003). Only the building of sewage treatment plants could stop and partly reverse the eutrophication of many lakes. In the course of the 20th century, traffic on the waterways changed from the transport of goods to tourism.

Mecklenburg-Western Pomerania is centrally located between the different immigration corridors of Europe (Bij de Vaate et al., 2002) and, due to this data situation, is particularly suitable for considering the current dynamics in the shift in species spectra.

\section{Results}

Currently 17 freshwater amphipod species live in Mecklenburg-Western Pomerania. Of these, five are considered autochthonous (one species is extinct) and 12 are allochthonous. Nine of these are of Ponto-Caspian origin (Tab. 1).

Gammarus pulex is unrivalled in small streams up to the headwater bodies. G. roeselii is typical for developed streams, ditches and larger receiving water bodies. Both species also colonize lakes, sometimes as the dominant species (Fig. 3). They are clearly in retreat when Ponto-Caspian species appear. A coexistence with Pontogammarus robustoides (G.O. Sars, 1894 ) and Dikerogammarus haemobaphes (Eichwald, 1841) can be observed at least during a transition period.

The current distribution of G. lacustris (Figs. 1-3) was the reason for this evaluation study, after amphipods were recorded in water bodies where none were suspected at all (Figs. 4-6). These are very small water bodies on the terminal moraine (main watershed). Their common feature is that they have no connection to other water bodies. Older data already showed the disappearance of G. lacustris from many previously known occurrences or the restriction to very isolated water body types, e.g. residual water bodies after the mining of peat, clay, loam, chalk or gravel. The centre of such occurrences is the island of Rugia. This island's inland is still largely uncoupled from trends of many new colonization's (e.g. G. roeselii, Ponto-Caspian amphipod species, or bivalves of the genus Dreissena). Another main area for the distribution of G. lacustris is the ridge of the main terminal moraine (Fig. 2). These water bodies are mostly the remains of dead ice hollows in the middle of intensively used agricultural landscapes. The survival of amphipods in these rather unsuitable water bodies (Figs. 4-6) often seems puzzling.

Our data on the distribution pattern of the amphipod species G. lacustris and G. roeselii show they are mutually exclusive. As soon as there is an open hydraulic connection from water bodies to downstream water bodies, G. lacustris is already replaced by G. pulex and G. roeselii. Data on the common occurrence of G. lacustris and G. pulex are available (albeit sparse), but the species is not associated with G. roeselii or with introduced Pontocaspian species. 
U. Meßner and M.L. Zettler: Knowl. Manag. Aquat. Ecosyst. 2021, 422, 17

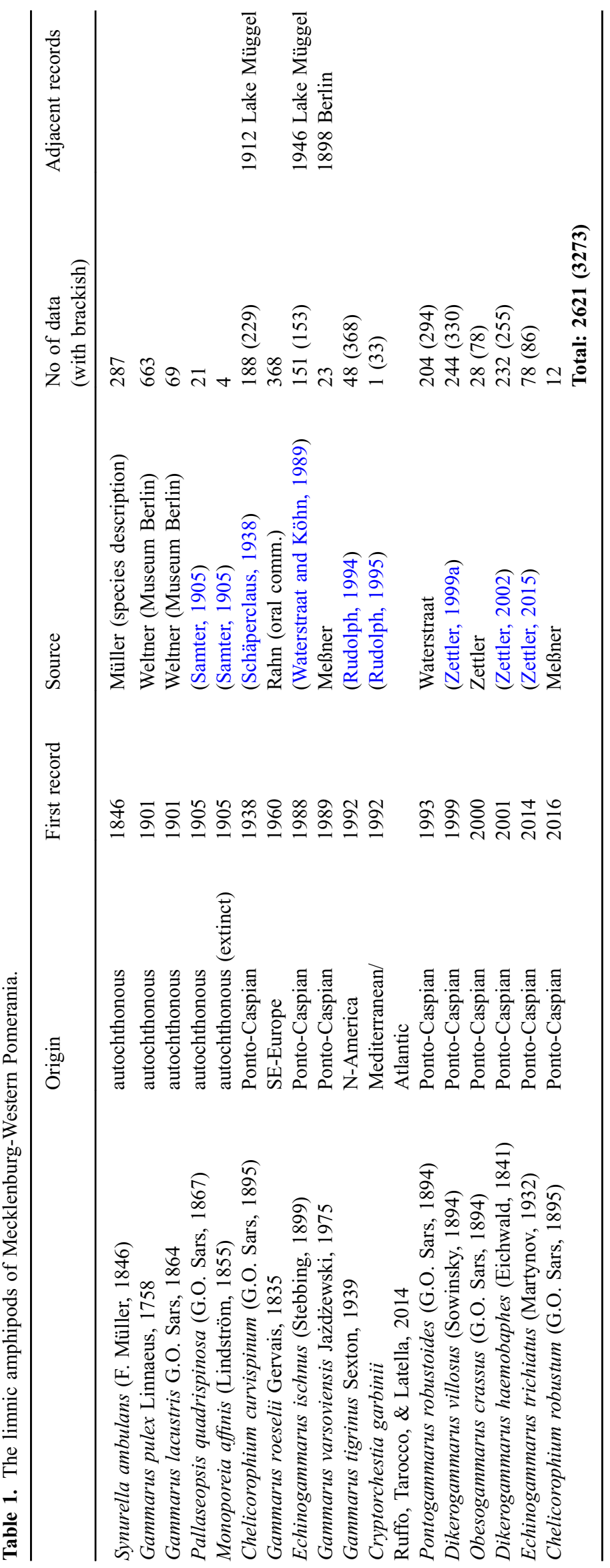

Page 4 of 8 


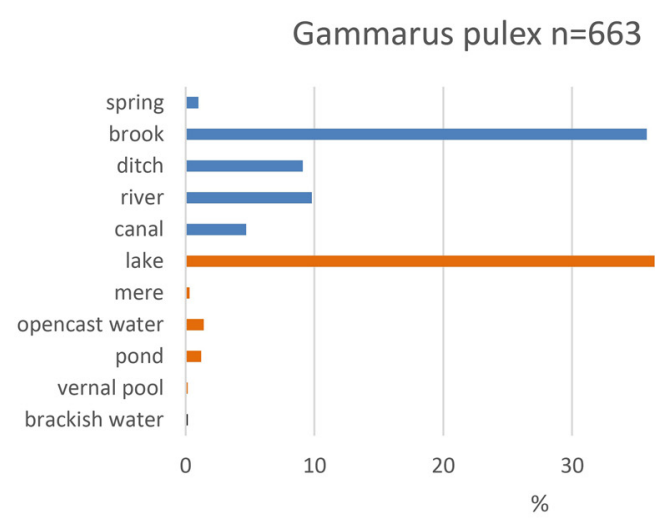

Gammarus roeselii $n=368$

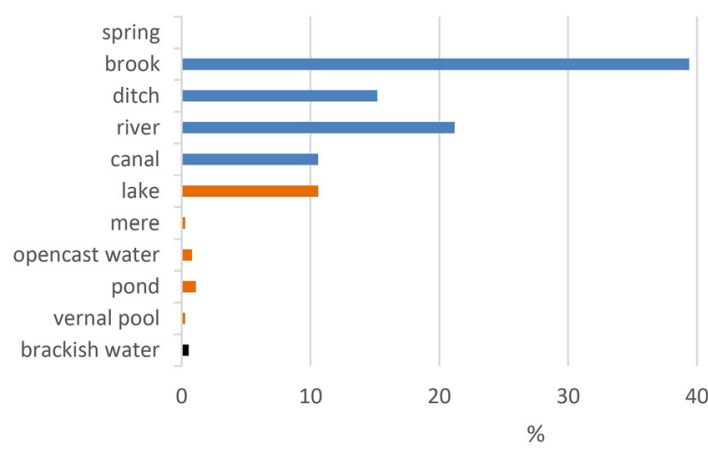

Gammarus lacustris $n=69$

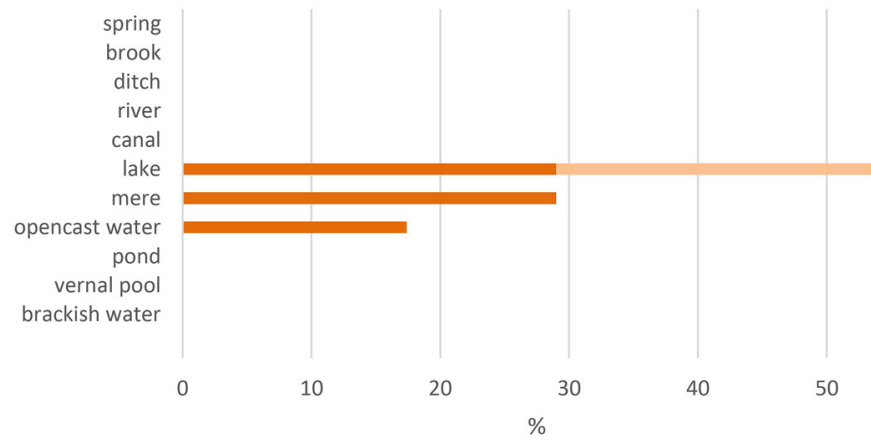

Fig. 3. The habitat preference of Gammarus pulex Linnaeus, 1758, Gammarus roeselii Gervais, 1835 and Gammarus lacustris G.O. Sars, 1864 clearly shows the restriction of G. lacustris to small standing water bodies and its withdrawal from lakes. Blue: running water bodies, orange: standing water bodies, light orange: extinct occurrences.

\section{Discussion}

We assume that G. lacustris, G. pulex and Synurella ambulans (F. Müller, 1846) belong to the original post Ice Age amphipod fauna of Northern Germany (Jażdżewski and Konopacka, 1993). Pallaseopsis quadrispinosa and Monoporeia affinis are distinct ice age relics. P. quadrispinosa currently still lives in the deep regions of three large lakes (Tollensesee, Schaalsee and Kummerower See). M. affinis has

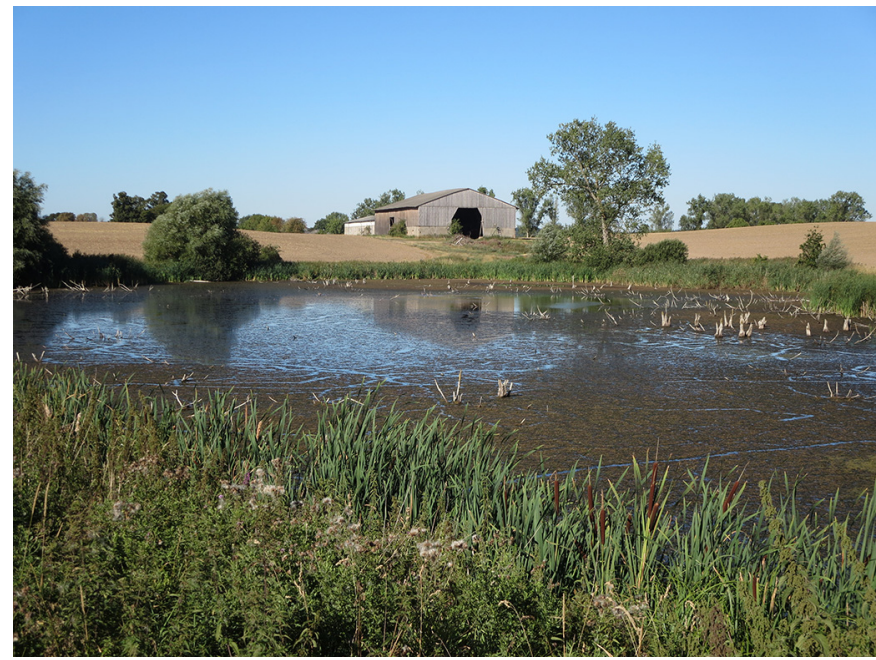

Fig. 4. Dead ice hollow near the village of Groß Flotow (locally known as 'Haferkuhle'), west of the city of Neubrandenburg. A small water body heavily stressed by eutrophication with abundant occurrence of Gammarus lacustris G.O. Sars, 1864.

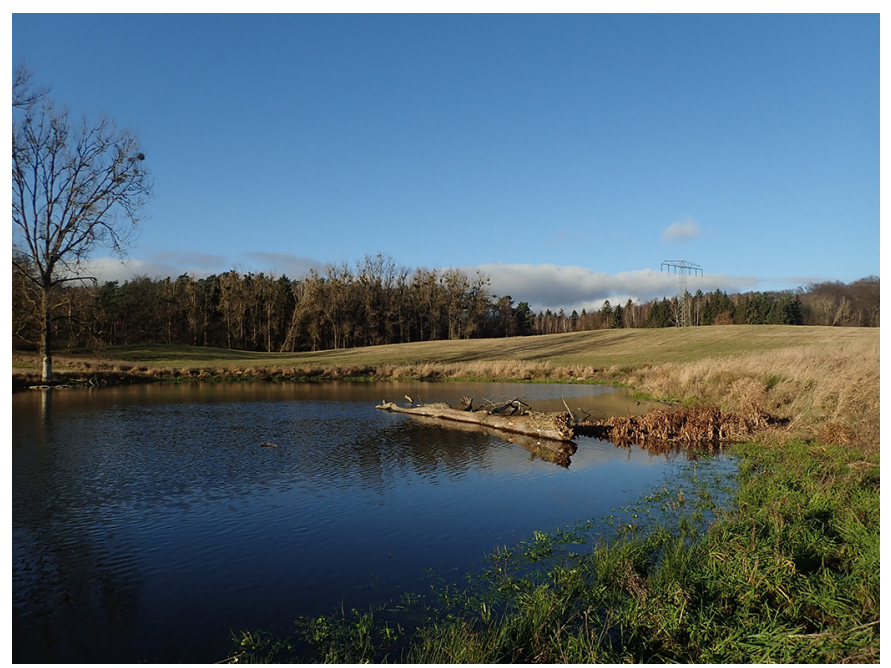

Fig. 5. Dead ice hollow on the 'Rosenthal' terminal moraine (southeast Mecklenburg).

been considered extinct/lost in inland water bodies for decades (Waterstraat, 1988; Zettler, 1998). S. ambulans is widespread and prefers headwater bodies in almost all types of water bodies as well as areas silting up.

We can only speculate about the immigration history of G. roeselii and G. varsoviensis. Both species have been in the area for longer than records suggest (Karaman and Pinkster, 1977; Jażdżewski and Roux, 1988; Grabowski et al., 2012). The first physical evidence of $G$. roeselii in our database dates back to 1988. But an oral communication of J. Rahn states that he knew this species for the lake Müritz as early as the 1960s is very credible. The early data of Schäperclaus (1938) and Wundsch (1948) are a reliable indication that at that time G. roeselii did not yet occur, at least not in the water bodies they investigated (Meßner and Zettler, 2016a). Today the 


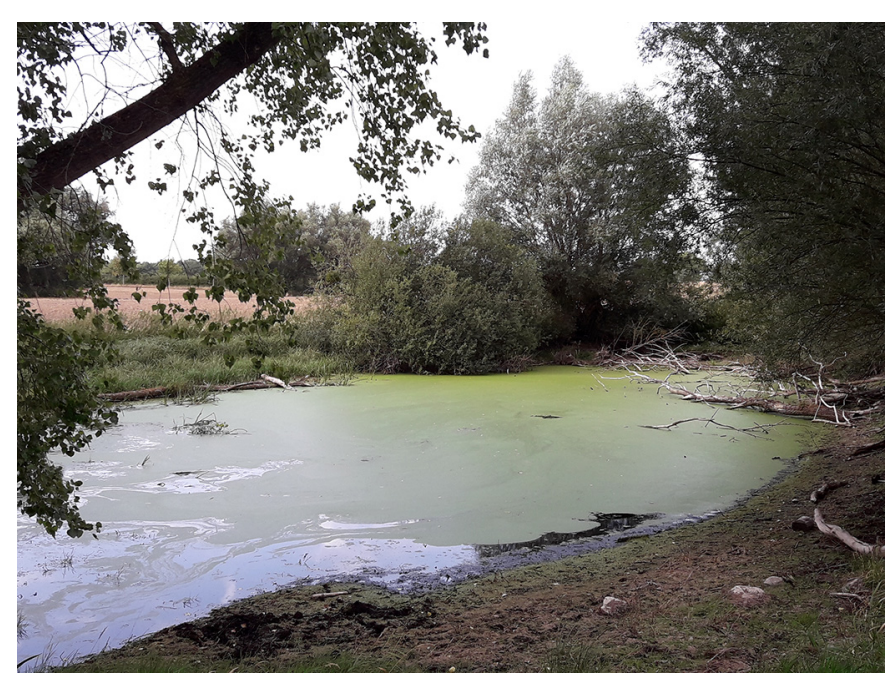

Fig. 6. Dead ice hollow in the agricultural landscape west of the city of Neubrandenburg with a sparse occurrence of Gammarus lacustris G.O. Sars, 1864 in the dry summer of 2018 . Only $150 \mathrm{~m}$ away from this site, a ditch drains the area where Gammarus pulex Linnaeus, 1758 and Gammarus roeselii Gervais, 1835 occur.

species is widely distributed in the upper and middle reaches of running water bodies and in lakes.

It remains unclear when $G$. varsoviensis immigrated. Old data can only be obtained from records (false identifications) of G. lacustris. According to this, the species was widespread in large lakes and waterways in the 1980s (own data; Vainio et al., 1995; Tab. 1). Current data is only available for a few lakes or short river sections. After a strong distribution in the past, today the species seems to have been overtaken by the new immigrated species (Meßner and Zettler, 2016a,b). The species is now extremely rare.

With the intensification of canal development and shipping traffic, C. curvispinum and E. ischnus have entered our area. Their discovery may also be well after first records exist (Tab. 1; Rudolph and Coleman, 2017). They initially only colonized the large lakes and waterways (Zettler, 1998).

Gammarus tigrinus Sexton, 1939 originated from North America. It reached our inland water bodies via shipping routes and from the Baltic Sea, after the species was released in 1957 in the river Werra (Hesse/Thuringia) as a replacement for non-salt-tolerant amphipods (Schmitz, 1960; Zettler, 2002). In Mecklenburg-Western Pomerania this species is restricted to the brackish waters and some larger rivers and lakes. The amphibious living Cryptorchestia garbinii Ruffo, Tarocco \& Latella, 2014 spreads along the European coasts and is also found in freshwater habitats. Recent studies (Ruffo et al., 2014; Davolos et al., 2018; Rewicz et al., 2020) indicate that the species that has migrated to Europe is Cryptorchestia garbinii, a species formerly called Cryptorchestia cavimana (Heller, 1865). The latter is probably restricted to Cyprus (see also Zettler and Zettler, 2017).

The appearance of the Ponto-Caspian species Pontogammarus robustoides, Dikerogammarus villosus (Sowinsky, 1894), Dikerogammarus haemobaphes, Obesogammarus crassus (G.O. Sars, 1894), Echinogammarus trichiatus (Martynov, 1932), and Chelicorophium robustum (G.O. Sars, 1895) caused a significant change in the waterways fauna. Their distribution was initially closely linked to the heavy shipping traffic. But now its distribution to other water bodies outside the waterways can be observed.

Looking at the distribution of amphipod species in the landscape (Fig. 2), the colonisation by newly immigrated species via the waterways is striking. At the same time, autochthonous species are disappearing from these habitats (Meßner and Zettler, 2016a,b). G. pulex is still the most common species in the entire study area, but it disappears with the appearance of the Ponto-Caspian species. The same applies to $G$. roeselii and $G$. varsoviensis.

It is also remarkable that the newly immigrated species occur almost simultaneously on both sides of the watershed. This was already noticeable for E. ischnus in the late 1980s (Waterstraat and Köhn, 1989; own data). This phenomenon could now be observed for all other new invasive species as well. There are also waters with these species that are unrelated to shipping. The only possible vectors are the transport of fry by fishing companies or recreational anglers (individual concrete cases in the area indicate that this is the probable cause) or the transfer of recreational boats.

In the Midwest of North America G. lacustris densities have decreased during the past 50 years while occurrence of fish and intensity of agriculture land use have increased markedly in this landscape (Anteau et al., 2011). These factors certainly play a role here too. However, if the intensification of the surrounding agriculture (eutrophication, use of pesticides) in Mecklenburg-Western Pomerania does not drive out G. lacustris, its resilience seems to be considerably higher than that of other amphipod species in this regard. The causes of the decline in most landscapes must be other than the usual explanatory pattern.

Today, the current distribution pattern allows the assumption that the immigration of $G$. roeselii led to the displacement of G. lacustris. A further indication of this is the settlement pattern of a number of isolated but closely neighbouring and very similar lakes in the Müritz National Park with either $G$. lacustris or $G$. roeselii. The entry of $G$. roeselii is very likely due to fish stocking in the past. The distribution patterns in Northern Germany suggest that G. lacustris is already extremely weak in competition with $G$. roeselii. This assumption is also supported by a study from Russia. In different aquatic ecosystems in Russia, a considerable decline in density or even the disappearance of the native $G$. lacustris was recorded in the case of G. lacustris and Gmelinoides fasciatus (Stebbing, 1899) (an introduced Baikalian amphipod) coexistence (Berezina, 2007 and references therein).

Our data does not permit the inter-species competition of the Ponto-Caspian species. This is because there has been no relevant encounter of $G$. lacustris with these species in Mecklenburg-Western Pomerania. The "confrontation" with known competitive Ponto-Caspian species did not take place in the sequence of historical events. However, the colonisation by the Ponto-Caspian species resulted in the disappearance of G. pulex and G. roeselii in the waterways and connected lakes (Fig. 2). 
The situation in the northwestern German lakes (Holstein) is different, but supporting our hypothesis. Here, G. roeselii is missing. Until the recent immigration of the Ponto-Caspian species, there were still good populations of G. lacustris. These only recently decreased significantly with the appearance of the Ponto-Caspian species (IGB, 2009; Otto, 2013; Otto and Speth, 2018; Otto, 2020).

It is also interesting to look at the distribution of species at the edge of the Alps, where G. lacustris, G. roeselii and $D$. villosus occur in Lake Constance. Here, too, there is a data gap on the immigration of $G$. roeselii. We assume that the species immigrated in the middle of the 20th century. This in turn led to a sharp decline of G. lacustris and its isolation in the Lower Lake Constance (Altermatt et al., 2019; LFU, 2005; http://www.neozoen-bodensee.de/aktuelles). The immigration of $D$. villosus and its competition to $G$. roeselii has become the subject of several studies there (Hesselschwerdt et al., 2008; Kley et al., 2009; Mayer et al., 2012).

Habitat loss through intensification of land use is the decisive factor for the decline of many species in the landscape. This does not seem to be the "whole story" for G. lacustris. In Northern Germany, the species lives at its southwest distribution limit, but is, as described above, extremely robust to undemanding with regard to the populated water bodies. The high tolerance of $G$. lacustris to environmental factors does not preclude a decline in its population density due to increased predation, shoaling, changes in the water mineralization, acidification, reduction or changes in the species composition of plant communities, and competition with other amphipods (Matafonov and Bazova, 2014 and references therein).

Our own observations from a geologically identical and similarly intensively used lake landscape in Denmark (catchment area of the Gudenå) show the common and apparently stable occurrence of G. pulex and G. lacustris in a network of large and small lakes. Here, both G. roeselii and the Ponto-Caspian species are missing.

The frequent assumption that climate change causes the retreat or spread of individual species is not very obvious for $G$. lacustris in the present study with regard to an increase in average temperatures. A number of occurrences exist in very shallow and sunny water bodies, which can become very warm in summer. We cannot confirm the sometimes-expressed assumption that $G$. lacustris is a cold-loving or cold-adapted species. However, if the change in the water balance leads to the drying up of these small water bodies in the future, these occurrences will continue to decrease (Fig. 6).

From our data it can be concluded that the massive decline of G. lacustris in northeast Germany historically results from competition with $G$. roeselii. In landscapes in which $G$. roeselii is not yet found, G. lacustris is either still widespread (Denmark) or is currently being displaced by Pontocaspian species (Schleswig-Holstein). In summary, it can be stated that the changes in the amphipod fauna in northeast Germany have accelerated sharply in the course of the 20th century. While the "old fauna" was almost unchanged for thousands of years from the end of the Ice Age, today we are witness to an unprecedented change in the fauna.

Acknowledgments. We especially thank Rebekka Meßner for designing the graphics.

\section{References}

Altermatt F, Alther R, Fišer C, Švara V. 2019. Amphipoda (Flohkrebse) der Schweiz. Fauna Helvetica 32, info fauna CSCF \& SEG, Neuchâtel, p. 392.

Anteau MJ, Afton AD, Anteau ACE, Moser EB. 2011. Fish and land use influence Gammarus lacustris and Hyalella azteca (Amphipoda) densities in large wetlands across the upper Midwest. Hydrobiologia 664: 69-80.

Berezina NA. 2007. Invasions of alien amphipods (Amphipoda: Gammaridea) in aquatic ecosystems of North-Western Russia: pathways and consequences. Hydrobiologia 590: 15-29.

Bij de Vaate A, Jazdzewski K, Ketelaars HAM, Gollasch S, Van der Velde G. 2002. Geographical patterns in range extension of PontoCaspian macroinvertebrate species in Europe. Can J Fish Aquat Sci 59: $1159-1174$.

Csapó H, Krzywoźniak P, Grabowski M, Wattier R, BącelaSpychalska K, Mamos T, Jelić M, Rewicz T. 2020. Successful post-glacial colonization of Europe by single lineage of freshwater amphipod from its Pannonian Plio-Pleistocene diversification hotspot. Sci Rep 10: 18695.

Davolos D, De Matthaeis E, Latella L, Tarocco M, Özbek M, Vonk R. 2018. On the molecular and morphological evolution of continental and insular Cryptorchestia species, with an additional description of C. garbinii (Talitridae). ZooKeys 783: 37-54.

Grabowski M, Rewicz T, Bącela-Spychalska K, Konopacka A, Mamos T, Jażdżewski K. 2012. Cryptic invasion of Baltic lowlands by freshwater amphipod of Pontic origin. Aquat Invas 7: $337-346$.

Grabowski M, Mamos T, Bącela-Spychalska K, Rewicz T, Wattier R. 2017. Neogene paleogeography provides context for understanding the origin and spatial distribution of cryptic diversity in a widespread Balkan freshwater amphipod. PeerJ 5: e3016.

Hesselschwerdt J, Necker J, Wantzen KM. 2008. Gammarids in Lake Constance: habitat segregation between the invasive Dikerogammarus villosus and the indigenous Gammarus roeselii. Fundam Appl Limnol 173: 177-186.

IGB. 2009. Untersuchung des eulitoralen Makrozoobenthos an sieben Seen in Schleswig-Holstein, Endbericht. Landesamt für Natur und Umwelt des Landes Schleswig-Holstein, p. 174.

Jażdżewski K, Konopacka A. 1993. Survey and distribution of Crustacea Malacostraca in Poland. Crustaceana 65: 176-191.

Jażdżewski K, Roux AL. 1988. Biogeographie de Gammarus roeseli Gervais en Europe, en particulier repartition en France et en Pologne. Crustaceana Suppl. 13: 272-277.

Kaiser K, Lorenz S, Germer S, Juschus O, Küster M, Libra J, Bens O, Hüttl RF. 2012. Late Quaternary evolution of rivers, lakes and peatlands in northeast Germany reflecting past climatic and human impact - an overview. E\&G Quat Sci J 61: 103-132.

Karaman GS, Pinkster S. 1977. Freshwater Gammarus species from Europe, North Africa and adjacent regions of Asia (Crustacea, Amphipoda). Part II. Gammarus roeseli-group and related species. Bijdragen tot de Dierkunde 47: 165-196.

Kley A, Kinzler W, Schank Y, Mayer G, Waloszek D, Maier G. 2009. Influence of substrate preference and complexity on co-existence of two non-native gammarideans (Crustacea: Amphipoda). Aquat Ecol 43: 1047-1059.

LFU. 2005. Wirbellose Neozoen im Bodensee. Landesanstalt für Umweltschutz Baden-Württemberg, Karlsruhe, p. 46.

Matafonov DV, Bazova NV. 2014. Decline of Gammarus lacustris Sars (Crustacea: Amphipoda) population in the delta of Selenga River. Biol Bull 41: 168-175. 
Mathes J, Korczynski I, Müller J. 2003. Shallow lakes in north-east Germany: trophic situation and restoration programmes. Hydrobiologia 506: 797-802.

Mayer G, Maas A, Waloszek D. 2012. Coexisting native and nonindigenous gammarideans in Lake Constance. Comparative morphology of mouthparts. Spixiana 35: 269-285.

Meßner U, Zettler ML. 2016a. Die Amphipodenfauna (Crustacea) zwischen Plauer See und Müritz (Mecklenburgische Seenplatte). Arch Natur- und Landeskunde Mecklenburg-Vorpommern 54: $43-55$.

Meßner U, Zettler ML. 2016b. Die aktuelle Verbreitung von Amphipoden (Crustacea) im Verlauf der Oberen Havel. Lauterbornia 81: 57-69.

Otto CJ. 2013. Validierung des Bewertungsverfahrens für Makrozoobenthos in Seen gemäß WRRL, Bericht im Auftrag des Landesamtes für Landwirtschaft, Umwelt und ländliche Räume des Landes Schleswig-Holstein (LLUR), Flintbek

Otto CJ. 2020. Untersuchung des Makrozoobenthos an sechs Seen in Schleswig-Holstein, Bericht im Auftrag des Landesamtes für Landwirtschaft, Umwelt und ländliche Räume des Landes Schleswig-Holstein (LLUR), Flintbek

Otto CJ, Speth S. (2018). Validierung des Bewertungsverfahrens für Makrozoobenthos (AESHNA Version Mai 2017) anhand der Daten aus 2012 und 2014 in Schleswig-Holstein gemäß WRRL, Bericht im Auftrag des Landesamtes für Landwirtschaft, Umwelt und ländliche Räume des Landes Schleswig-Holstein (LLUR), Flintbek.

Rewicz T, Brodecki J, Bącela-Spychalska K, Konopacka A, Grabowski M. 2020. Further steps of Cryptorchestia garbinii invasion in Polish inland water bodies with insights into its molecular diversity in Central and Western Europe. Knowl Manag Aquat Ecosyst 421, 17.

Rudolph K. 1994. Erstnachweis des Amphipoden Gammarus tigrinus Sexton, 1939 (Crustacea: Gammaridea) im Peenestrom und Achterwasser (südliche Ostseeküste). Naturschutzarbeit Mecklenburg-Vorpommern 37: 23-29.

Rudolph K. 1995. Zum Vorkommen des Strandflohkrebses Orchestia cavimana im vorpommerschen Küstengebiet und zur Frage seiner Überwinterung. Natur und Museum 125: 281-285.

Rudolph K, Coleman CO. 2017. Nachweis von Echinogammarus ischnus (Stebbing, 1899) in einer Probe aus Berlin, aus dem Jahre 1946. Lauterbornia 84: 109-111.

Ruffo S, Tarocco M, Latella L. 2014. Cryptorchestia garbinii n. sp. (Amphipoda: Talitridae) from Lake Garda (Northern Italy), previously referred to as Orchestia cavimana Heller, 1865, and notes on the distribution of the two species. Ital $J$ Zool 81: 92-99.

Samter M. 1905. Die geographische Verbreitung von Mysis relicta, Pallasea quadrispinosa, Pontoporeia affines in Deutschland als Erklärungsversuch ihrer Abstammung. Abhandlungen der
Königlich Preussischen Akademie der Wissenschaften Berlin, Anhang: 1-40.

Schäperclaus W. 1938. Auszug aus dem Gutachten der Reichsanstalt für Fischerei vom 21. Oktober 1938. 5 S. (in Wundsch, 1948)

Schmitz W. 1960. Die Einbürgerung von Gammarus tigrinus Sexton auf dem europäischen Kontinent. Arch Hydrobiol 7: 223-225.

Schönfelder I, Steinberg CEW. 2004. How did the nutrient concentrations change in northeastern German lowland rivers during the last four millennia? - A paleolimnological study of floodplain sediments. Stud Quat 21: 129-138.

Segerstråle SG. 1954. The freshwater amphipods Gammarus pulex (L.) and Gammarus lacustris G.O. Sars, in Denmark and Fennoscandia - a contribution to the late- and postglacial immigration history of the aquatic fauna of northern Europe. Societas Scienciarum Fennica. Comment Biol 15: 1-91.

Tittizer T. 2001. Neozoen in mitteleuropäischen Gewässern. Rundg Kommission Ökolog 22: 59-74.

Tittizer T, Scholl F, Banning M, Haybach A, Schleuter M. 2000. Aquatische Neozoen im Makrozoobenthos der BinnenwasserstraBen Deutschlands. Lauterbornia 39: 1-72.

Vainio JK, Jażdżewski K, Väinölä R. 1995. Biochemical systematic relationships among the freshwater amphipods Gammarus varsoviensis, G. lacustris and G. pulex. Crustaceana 68: 687-694.

Waterstraat A, Köhn J. 1989. Ein Beitrag zur Fauna des Kummerower Sees, Erstnachweis des Amphipoden Echinogammarus ischnus Stebbing, 1899 in der DDR. Arch Freunde Naturgeschichte Mecklenburg 39: 93-106.

Wundsch HH. 1948. Die produktionsbiologischen Verhältnisse der Müritz nach Ergebnissen der quantitativen Bodenuntersuchungen vom 12.-13.5.1948, Gutachten der Deutschen Forschungsanstalt für Fischerei Berlin, p. 21.

Zettler ML. 1998. Zur Verbreitung der Malacostraca (Crustacea) in den Binnen- und Küstengewässern von Mecklenburg-Vorpommern. Lauterbornia 32: 49-65.

Zettler ML. 1999a. Erstnachweis von Dikerogammarus villosus (Sovinski, 1894) und Wiederfund von Gammarus varsoviensis Jażdżewski, 1975 in Mecklenburg-Vorpommern (Crustacea: Amphipoda). Arch Freunde der Naturgeschichte Mecklenburg 38: 231-233.

Zettler ML. 1999b. Rote Liste der gefährdeten höheren Krebse der Binnengewässer Mecklenburg-Vorpommern. Umweltministerium Mecklenburg-Pomerania.

Zettler ML. 2002. Crustaceologische Neuigkeiten aus MecklenburgVorpommern. Arch Freunde der Naturgeschichte Mecklenburg 41: $15-36$.

Zettler ML. 2015. Kurze Notiz über die "Ankunft" von Echinogammarus trichiatus im Ostseegebiet und den Erstnachweis von Paramysis lacustris in Deutschland. Lauterbornia 79: 151-156.

Zettler ML, Zettler A. 2017. Marine and freshwater Amphipoda from the Baltic Sea and adjacent territories, Conchbooks, Harxheim, p. 845.

Cite this article as: Meßner U, Zettler ML. 2021. Drastic changes of the amphipod fauna in northern Germany and the displacement of Gammarus lacustris G.O. Sars, 1864 to relict habitats/status. Knowl. Manag. Aquat. Ecosyst., 422, 17. 